\title{
Peran Operasi Kasai pada Pasien Atresia Bilier yang Datang Terlambat
}

\author{
Elina Waiman, Hanifah Oswari
}

Departemen Ilmu Kesehatan Anak, RS Dr Cipto Mangunkusumo, Fakultas Kedokteran Universitas Indonesia, Jakarta

\begin{abstract}
Kasus atresia bilier di Departemen Ilmu Kesehatan Anak RS Dr Cipto Mangunkusumo Jakarta selama sepuluh tahun terakhir mengalami peningkatan. Namun disayangkan pasien pada umumnya datang berobat terlambat, sehingga telah terjadi sirosis bilier dengan prognosis buruk. Operasi Kasai merupakan pilihan tata laksana utama pasien dengan atresia bilier, karena keterbatasan melakukan transplantasi hati di Indonesia. Dari penelusuran literatur didapatkan bahwa keberhasilan operasi Kasai dipengaruhi oleh berbagai faktor, antara lain keadaan histologi hati dan tipe atresia bilier, kadar bilirubin serum dan kejadian kolangitis asenden pascaoperasi, serta pengalaman pusat pelayanan yang bersangkutan dalam melakukan operasi Kasai dan perawatan pascaoperasi. Apabila operasi dilakukan pada pasien yang berusia lebih dari enampuluh hari, umumnya hasil tidak memuaskan. Namun, beberapa peneliti melaporkan sejumlah pasien yang dioperasi pada usia lebih dari enampuluh hari memiliki kesintasan hingga 10-15 tahun pascaoperasi. Hal ini menjadi peringatan kepada petugas kesehatan terutama dokter anak agar dapat mendeteksi atresia secara dini dan merujuk pada saat yang tepat sehingga meningkatkan kesintasan jangka panjang pasien atresia bilier. Edukasi dan informasi kepada masyarakat mengenai bayi yang mengalami kuning berkepanjangan tampaknya perlu disosialisasi kembali. (Sari Pediatri 2010;11(6):463-70).
\end{abstract}

Kata kunci: atresia bilier, usia enampuluh hari, prognosis, operasi Kasai.

A tresia bilier merupakan penyakit hati yang ditandai dengan obstruksi dan fibro-obliterasi progresif saluran bilier ekstrahepatik. Sampai saat ini penyebab atresia bilier belum diketahui. Kejadian atresia bilier dilaporkan antara

\footnotetext{
Alamat korespondensi:

DR. Dr. Hanifah Oswari, Sp.A(K). Departemen Ilmu Kesehatan Anak FKUI/RSCM Jl. Salemba 6 Jakarta. Telp/fax 021-3915712. Email: hoswari@gmail.com
}

1:8000 sampai 1:18000 kelahiran hidup. ${ }^{1,2}$ Atresia bilier merupakan penyebab penyakit hati terminal yang merupakan indikasi utama transplantasi hati pada anak. ${ }^{3}$ Gejala awal atresia bilier seringkali sulit dibedakan dengan ikterus neonatorum fisiologis, sehingga diagnosis dan tata laksana menjadi terlambat. Penyebab lain keterlambatan diagnosis adalah adanya beberapa diagnosis banding sebagai penyebab hiperbilirubinemia direk yang memerlukan waktu untuk penegakan diagnosis. ${ }^{1}$ 
Operasi portoenterostomi oleh Kasai yang ditemukan pada tahun 1959 merupakan terobosan besar dalam tata laksana atresia bilier. Dilaporkan bahwa kesintasan operasi Kasai lebih tinggi pada pasien yang dioperasi pada usia kurang dari 2 bulan. ${ }^{4-7}$ Operasi Kasai menjadi satu-satunya upaya pengobatan untuk mempertinggi kesempatan hidup pasien atresia bilier, karena keterbatasan melakukan transplantasi hati di Indonesia.

Dalam duabelas tahun terakhir (tahun 19982009), pasien baru atresia bilier yang berobat ke Departemen Ilmu Kesehatan Anak RS Dr Cipto Mangunkusumo (IKA RSCM) berjumlah 60 orang, tampak kecenderungan jumlah pasien yang semakin meningkat. Pada tahun 1998-2001, terdapat tiga pasien, pada tahun 2002-2005 terdapat 23 pasien, dan pada tahun 2006-2009 terdapat 34 pasien atresia bilier. Median usia saat berobat adalah 4 bulan 3 minggu. Jumlah pasien yang berobat pada usia kurang dari dua bulan hanya 12 orang (20\%). Tingginya angka keterlambatan dalam kunjungan pertama kali ini menimbulkan kepedulian tentang peran operasi Kasai terhadap kesintasan jangka panjang pasien atresia bilier yang datang pada usia lebih dari 2 bulan.

\section{Kasus}

Seorang bayi perempuan, usia 5 bulan, datang pertama kali ke Poliklinik Hepatologi Anak RSCM pada tanggal 14 Oktober 2009 dengan keluhan utama bayi menderita kuning sejak usia satu minggu. Pasien dirujuk oleh dokter spesialis anak di RS GAB dengan keterangan kolestasis intrahepatik, dengan diagnosis banding kolestasis ekstrahepatik. Pada usia satu minggu, pasien dirawat di RS GAB dengan diagnosis diare akut dehidrasi berat, sepsis, ensefalopati metabolik, dan kolestasis intrahepatik. Saat itu pasien mulai tampak kuning, buang air besar mulai berwarna dempul, dan buang air kecil berwarna kuning tua. Pasien dirawat selama dua minggu dan dianjurkan untuk menjalani pemeriksaan ultrasonografi hati di RSCM, namun keluarga pasien menolak karena alasan biaya. Pada usia dua bulan, pasien mengalami infeksi saluran kemih berulang dan dirawat selama 10 hari. Hasil pemeriksaan bilirubin total $10,7 \mathrm{mg} / \mathrm{dL}$, bilirubin direk 9,1 mg/dL, bilirubin indirek 1,6 mg/dL, SGOT 192 U/L, SGPT 39 U/L, dan $\gamma$ GT 322 U/L. Pasien kembali dirujuk ke RSCM, namun keluarga pasien menolak. Pasien mendapatkan asam ursodeoksikolat dan multivitamin. Pada usia lima bulan, bayi tetap kuning dan belum berkurang maka orangtua pasien setuju untuk dirujuk ke RSCM.

Saat datang ke RSCM, pasien tampak kuning, perut membuncit, tidak terdapat perdarahan, buang air besar berwarna dempul, dan buang air kecil kuning tua. Pada pemeriksaan fisis didapatkan berat badan $6,5 \mathrm{~kg}$ (P25-50 kurva CDC 2000) dan tinggi badan $65 \mathrm{~cm}$ (P50 kurva CDC 2000). Pada pemeriksaan mata didapatkan konjungtiva pucat dan sklera ikterik. Pemeriksaan jantung dan paru dalam batas normal. Pada perabaan abdomen dijumpai pembesaran hati lima sentimeter di bawah arkus kosta dan lima sentimeter di bawah processus xiphoideus, keras, tepi tumpul, permukaan rata, dan dijumpai asites. Limpa tidak teraba dan pada ekstremitas tidak ditemukan edema. Hasil pemeriksaan laboratorium menunjukkan anemia mikrositik hipokrom dengan $\mathrm{Hb} 9,3 \mathrm{~g} / \mathrm{dL}$, albumin $2,74 \mathrm{~g} / \mathrm{dL}$, bilirubin total $12,45 \mathrm{mg} / \mathrm{dL}$, bilirubin direk $10,51 \mathrm{mg} / \mathrm{dL}$ (rasio bilirubin direk dibanding total $84 \%$ ), bilirubin indirek 1,94 mg/dL, SGOT $282 \mathrm{~g} / \mathrm{dL}$, SGPT 160 g/dL, PT 20,2 detik (normal 13-17 detik), GT 218 U/L, alkali fosfatase 553 U/L, kolesterol 268 $\mathrm{mg} / \mathrm{dL}$. Pada biakan urin ditemukan K. pneumoniae (8000 kuman $/ \mathrm{mL})$. Pada pemeriksaan analisis feses didapatkan malabsorpsi lemak (3+). Sedangkan pada pemeriksaan ultrasonografi hati didapatkan parenkim hati yang sebagian tidak homogen dengan tepi sebagian tidak rata, kandung empedu tidak tervisualisasi, dan terdapat gambaran triangular cord di sekitar vena porta utama, gambaran tersebut sesuai dengan atresia kandung empedu. Biopsi hati memperlihatkan pigmen hijau intrasitoplasmik dalam kanalikuli di zona 1 dan 3 yang sebagian membentuk bile plug di duktulus, area portal berserbukan sel radang menahun dan mendadak, disertai fibrosis jembatan antarportal, tampak proliferasi duktulus nyata dan fibrosis periduktal, terdapat sel datia, namun bukan synticial giant cell, destruksi duktus biliaris meragukan, dan terdapat nekrosis fokal minimal. Gambaran biopsi hati sesuai dengan sirosis bilier akibat atresia saluran bilier ektrahepatik.

Diagnosis kerja ditegakkan pada pasien adalah kolestasis ekstrahepatik et causa atresia bilier, anemia et causa penyakit kronik dengan diagnosis banding anemia defisiensi besi. Pasien mendapatkan terapi diet Pregestimil ${ }^{\circledR}$, asam ursodeoksikolat $3 \times 75 \mathrm{mg}$, Akta-vol $^{\circledR}$ (vitamin A dan D) $2 \times 0,5 \mathrm{~mL}$, vitamin E 1x100 IU, dan vitamin $\mathrm{K} 1 \mathrm{mg}$ intramuskular. Transfusi packed red 
cell, fresh frozen plasma, dan albumin diberikan sebagai persiapan operasi Kasai. Pada laparatomi eksplorasi didapatkan gambaran makroskopis hati sirosis berat, berbenjol-benjol, keras, dan berwarna kehitaman. Kolangiografi intraoperatif memperlihatkan kontras yang tidak masuk ke dalam duktus sistikus dan sebagian besar kontras tumpah. Pasien didiagnosis dengan atresia bilier tipe 3. Saat operasi berlangsung, orangtua pasien diberikan keterangan dan edukasi tentang kondisi pasien dan kemungkinan prognosis apabila dilakukan dan tidak dilakukan operasi Kasai, namun orangtua menolak untuk menjalani operasi Kasai. Biopsi hati intraoperatif memperlihatkan adanya sel datia hepatosit, hemopoeisis ekstramedular, proliferasi duktus dan duktulus yang sangat mencolok, kolestasis keras intrasel sampai dengan duktus, serta fibrosis antarportal, yang sesuai dengan sirosis bilier oleh atresia bilier ekstrahepatik.

\section{Masalah klinis}

Beberapa penelitian memperlihatkan keberhasilan operasi Kasai lebih tinggi bila dilakukan pada usia yang lebih muda (kurang dari enampuluh hari).,4-9 Namun sebagian besar pasien dirujuk ke Departemen IKA RSCM pada usia yang umumnya "terlambat", yaitu lebih dari enampuluh hari. Berdasarkan masalah klinis tersebut, diajukan pertanyaan klinis: "Apakah operasi Kasai dapat memperpanjang masa hidup pasien atresia bilier yang berusia lebih dari enampuluh hari dibandingkan tanpa operasi Kasai?"

\section{Metode penelusuran literatur}

Untuk menjawab pertanyaan klinis tersebut, dilakukan penelusuran pustaka secara online dengan penggunakan instrumen pencari Pubmed, Highwire, dan Google. Kata kunci yang dipergunakan adalah "biliary atresia", "Kasai", dan "prognosis", dengan menggunakan batasan studi yang dilakukan pada manusia, dan publikasi berbahasa Inggris. Dengan metode tersebut, didapatkan 132 artikel yang memenuhi kriteria. Setelah penelusuran abstrak artikel-artikel tersebut, didapatkan 16 artikel yang relevan dengan masalah, yaitu 15 artikel kohort dan 1 artikel laporan kasus. Levels of evidence ditentukan berdasarkan klasifikasi yang dikeluarkan oleh Oxford Centre for Evidence-based Medicine Levels of Evidence. ${ }^{10}$

\section{Hasil penelusuran literatur}

Melalui operasi Kasai yang diikuti keberhasilan transplantasi hati, kesempatan hidup pasien atresia bilier menjadi lebih baik. Kesintasan keseluruhan empat tahun pascaoperasi berkisar 87,1\%-89\%, sedangkan kesintasan pada sepuluh tahun $66,7 \% .{ }^{11}$ Di negara-negara maju, pasien dengan atresia bilier umumnya dirujuk untuk menjalani operasi Kasai pada usia kurang dari enampuluh hari. Parameter keberhasilan jangka panjang operasi Kasai ditentukan oleh kesintasan dengan native liver, yaitu kesintasan dengan hati asli sampai pasien meninggal atau dilakukannya transplantasi hati. Perbandingan kesintasan pasien yang menjalani dan tidak menjalani operasi Kasai tertera pada Tabel 1. Penelitian yang membahas kesintasan pasien pascaoperasi Kasai yang dirujuk pada usia lebih dari enampuluh hari masih terbatas (Tabel 2), karena di negara maju jumlah pasien yang dirujuk pada kelompok usia ini lebih sedikit.

Toyosaka A dkk ${ }^{14}$ melaporkan kasus atresia bilier di Jepang yang menjalani operasi Kasai pada usia 9 bulan. Kolesistografi intraoperatif menunjukkan hasil tidak adanya hubungan antara duktus biliaris

Tabel 1. Perbandingan kesintasan pasien atresia bilier dengan dan tanpa operasi Kasai

\begin{tabular}{cccc}
\hline $\begin{array}{c}\text { Kesintasan dengan } \\
\text { native liver (tahun) }\end{array}$ & $\begin{array}{c}\text { Tanpa Kasai } \\
(\%)^{3,12}\end{array}$ & $\begin{array}{c}\text { Operasi Kasai } \\
\text { usia }<60 \text { hari }(\%)^{3,9}\end{array}$ & $\begin{array}{c}\text { Operasi Kasai } \\
\text { usia }>60 \text { hari }(\%)^{2-4,9,13}\end{array}$ \\
\hline 2 & $10-28,4$ & $57-70$ & $0-67$ \\
$4-5$ & 2,2 & $23-58,1$ & $15,8-40$ \\
10 & - & $36,1-42,5$ & $10,5-32,3$ \\
15 & - & $33,3-40,5$ & $13,4-28,7$ \\
\hline
\end{tabular}

Sari Pediatri, Vol. 11, No. 6, April 2010 
Elina Waiman dkk: Peran operasi Kasai pasa pasien atresia bilier yang datang terlambat

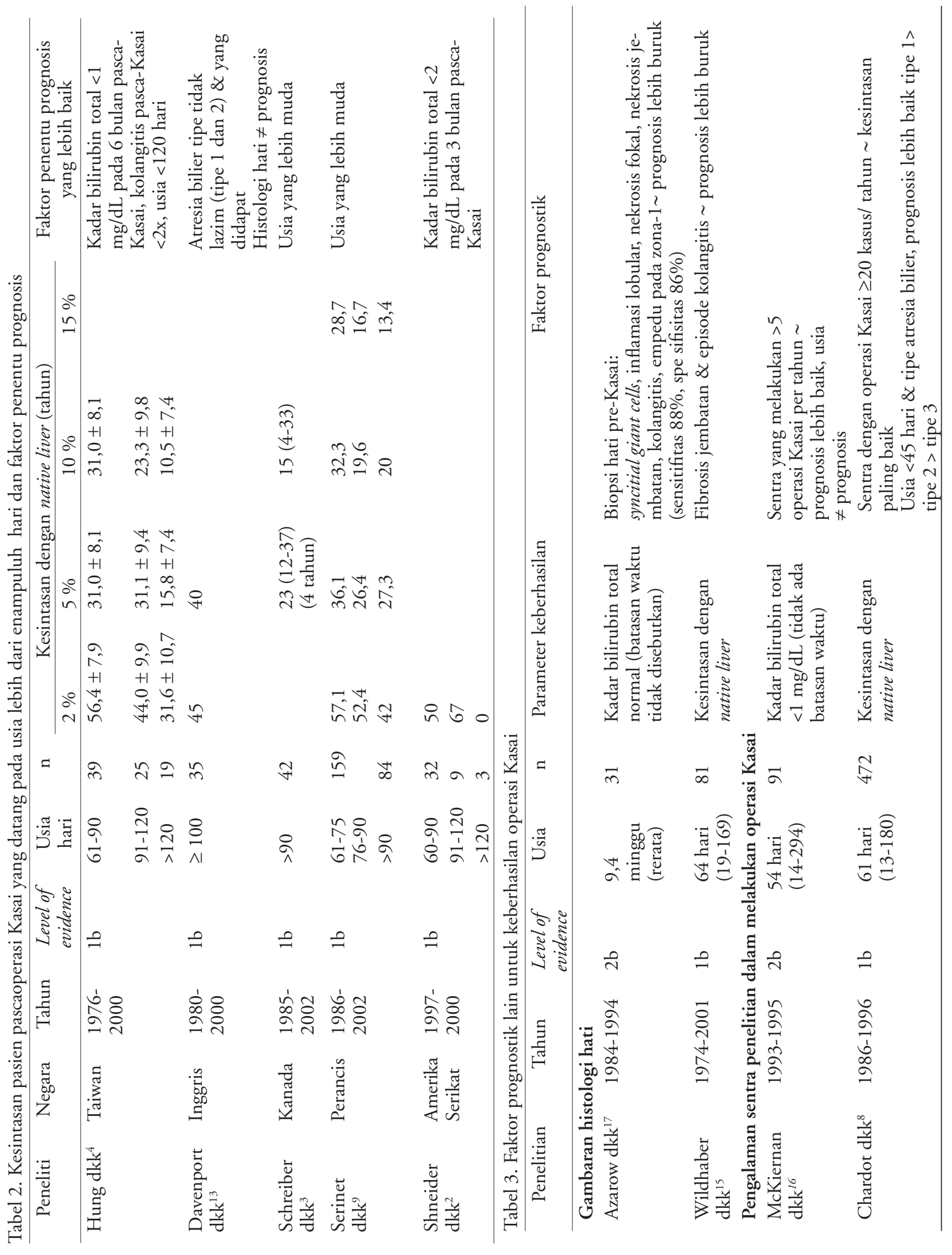


intrahepatik dan duodenum, serta pada duktus biliaris komunis didapatkan kista berukuran satu $\mathrm{cm}$. Pasien kemudian menjalani operasi Kasai. Biopsi hati memperlihatkan fibrosis hati derajat II dan III, namun tidak terdapat gambaran sirosis, terdapat infiltrasi selular dan proliferasi duktus biliaris pada daerah porta, serta terdapat endapan empedu pada duktus biliaris di daerah porta. Dua bulan pasca operasi, pasien tidak kuning, dan pada usia enam tahun satu bulan pasien sehat dan hidup secara normal (level of evidence: 4 ).

Hung $\mathrm{P} \mathrm{dkk^{4 }}$ melakukan penelitian pada 163 pasien di Taiwan dengan median usia 64 (rentang 26-298) hari. Seratus empatpuluh satu di antaranya menjalani pemantauan jangka panjang (angka lost to follow-up 14\%). Luaran pada penelitian ini adalah kesintasan dengan native liver, namun peneliti tidak menyebutkan apakah karakteristik klinis maupun faktor prognostik ditetapkan secara tersamar. Pada analisis multivariat didapatkan kadar bilirubin total kurang dari $1 \mathrm{mg} / \mathrm{dL}$ pada enam bulan pascaoperasi dan kejadian kolangitis pascaoperasi kurang dari dua kali merupakan faktor prognostik independen terhadap kesintasan pasien. Pasien yang menjalani operasi pada usia lebih dari 120 hari memperlihatkan aliran empedu (diukur dengan warna feses) lebih buruk (84\% versus $63 \%)$ dan angka bebas ikterik yang lebih rendah $(66 \%$ versus $31 \%$ ) dibandingkan pasien yang dioperasi pada usia kurang dari 120 hari. Kesintasan 5 dan 10 tahun masing-masing berkisar 15,8\%-44\% dan 10,5\%$39,6 \%$ (level of evidence: $1 \mathrm{~b}$ ).

Davenport $\mathrm{M} \mathrm{dkk}^{13}$ melakukan penelitian pada 35 pasien atresia bilier di Inggris yang dioperasi pada usia 100 hari atau lebih, dengan median 133 (rentang 108-180) hari. Penelitian dibatasi dengan menganalisis operasi yang dilakukan setelah tahun 1980 untuk menghindari efek learning curve akibat pembelajaran teknik operasi yang baru. Analisis kesintasan dilakukan selama lima tahun dan pemantauan berhasil dilakukan pada semua pasien. Angka kesintasan pada dua dan lima tahun dengan native liver masing-masing 45\% dan $40 \%$. Pasien dengan atresia bilier yang tidak lazim (tipe 1 dan 2) atau jenis atresia bilier yang didapat memiliki kecenderungan kesintasan yang lebih baik, namun secara statistik tidak bermakna. Adapun tipe makroskopis atresia bilier tertera pada Gambar 1. Penelitian Davenport $M$ dkk ini menunjukkan bahwa gambaran histologi yaitu derajat fibrosis, transformasi giant cell, dan destruksi duktus biliaris tidak memengaruhi prognosis pasien. Peneliti berkesimpulan bahwa kesintasan jangka menengah pasien atresia bilier yang datang pada usia 100 hari atau lebih masih cukup tinggi dan peneliti menyarankan dilakukannya operasi Kasai terlebih dahulu dibandingkan transplantasi hati, bila pertimbangan hanya didasarkan pada faktor usia (level of evidence: $1 \mathrm{~b}$ ).

Schreiber R dkk ${ }^{3}$ melakukan penelitian di Kanada pada 349 pasien atresia bilier, median usia saat dilakukan operasi Kasai adalah 65 (rentang 6-200) hari. Operasi Kasai dilakukan pada 312 dari 349 pasien dan pemantauan jangka panjang berhasil dilakukan pada semua pasien. Luaran berupa kesintasan dengan native liver dibandingkan antara pasien yang dioperasi $\leq 30$ hari, yang dioperasi 31-90 hari, dan yang dioperasi $>90$ hari. Hasil menunjukkan kesintasan tertinggi didapatkan pada pasien yang dioperasi pada usia $\leq 30$ hari (kesintasan sepuluh tahun $49 \%$ bila dioperasi pada usia $\leq 30$ hari, $25 \%$ bila dioperasi pada usia 31-90 hari, dan $15 \%$ bila dioperasi pada usia $>90$ hari). Seorang pasien menjalani operasi Kasai pada usia 115 hari, dan tetap hidup sampai sepuluh tahun pascaoperasi (level of evidence: $1 \mathrm{~b})$.

Serinet $\mathrm{M} \mathrm{dkk}^{9}$ melakukan penelitian pada 695 pasien atresia bilier yang menjalani operasi

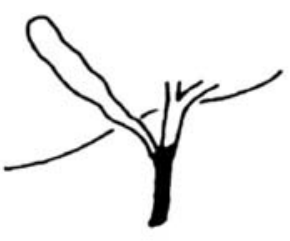

Tipe 1

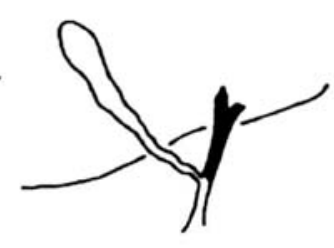

Tipe 2

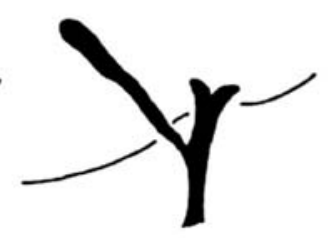

Tipe 3

Gambar 1. Tipe atresia bilier. Tipe I obliterasi segmental duktus biliaris komunis; tipe II obliterasi segmental duktus hepatikus; tipe III obliterasi seluruh duktus biliaris sampai ke tingkat porta hepatis. ${ }^{4}$

Sari Pediatri, Vol. 11, No. 6, April 2010 
Kasai di Perancis, dengan median usia saat operasi 60 hari (rentang 12-180 hari) dan median lama pengamatan berkisar tujuh tahun. Penelitian tersebut memperlihatkan kesintasan dengan native liver menurun dengan meningkatnya usia saat operasi $(p<0,001)$. Hasil terbaik didapatkan pada pasien yang menjalani operasi pada usia kurang dari tigapuluh hari. Pasien yang menjalani operasi pada usia lebih dari sembilanpuluh hari mempunyai kesintasan $13 \%$ untuk dapat bertahan hidup dengan native liver hingga masa remaja (level of evidence: $1 \mathrm{~b}$ ).

Shneider BL $\mathrm{dkk}^{2}$ melakukan penelitian pada 104 pasien yang menjalani operasi Kasai, dengan usia median saat dilakukan operasi 61 (rentang 11-153) hari. Pengamatan berhasil dilakukan pada 100 pasien (angka lost to follow-up 4\%) dan waktu pengamatan berlangsung selama dua tahun. Luaran yang diukur adalah kesintasan dengan native liver. Kesintasan pascaoperasi Kasai lebih baik pada pasien dengan kadar bilirubin total $<2 \mathrm{mg} / \mathrm{dL}$ dibandingkan pasien dengan kadar bilirubin total $>6 \mathrm{mg} / \mathrm{dL}$ pada tiga bulan pascaoperasi ( $84 \%$ versus $16 \%, p<0,0001)$ (level of evidence: $1 \mathrm{~b})$.

Beberapa penelitian (Tabel 3) memperlihatkan bahwa usia bukan merupakan penentu utama keberhasilan operasi Kasai. Pada umumnya peneliti mendefinisikan keberhasilan operasi dengan parameter kadar bilirubin serum pascaoperasi Kasai. Kadar bilirubin pascaoperasi ini merupakan salah satu faktor prognostik untuk memprediksi kesintasan jangka panjang pascaoperasi Kasai. ${ }^{4,15,16}$

\section{Pembahasan}

Selama beberapa dekade terakhir, operasi Kasai telah menjadi standar operasi pasien atresia bilier di seluruh dunia. Beberapa penelitian telah memperlihatkan kesintasan pascaoperasi Kasai yang lebih baik bila dilakukan pada usia yang lebih muda. Tata laksana untuk pasien yang berusia lebih 'tua' seringkali masih menjadi perdebatan, apakah sebaiknya menjalani operasi Kasai, atau langsung menjalani transplantasi hati. Namun transplantasi hati juga mempunyai berbagai kekurangan. Seorang anak yang menjalani transplantasi hati harus mendapatkan obat imunosupresif seumur hidup, yang meningkatkan risiko terkena infeksi, keganasan, dan kerusakan multiorgan. ${ }^{18}$

Tabel 1 memperlihatkan kesintasan pasien yang menjalani operasi setelah usia enampuluh hari lebih rendah dibandingkan pasien yang dioperasi pada usia kurang dari enampuluh hari. Walaupun demikian, kesintasan pada usia lima tahun berkisar antara 15,8\%$40 \%$, pada usia sepuluh tahun $10,5 \%-32,3 \%$, dan pada usia limabelas tahun 13,4\%-28,7\%. Angka tersebut masih cukup tinggi bila dibandingkan dengan pasien yang tidak menjalani operasi Kasai, yang umumnya sudah meninggal pada usia kurang dari tiga tahun. ${ }^{3}$

Faktor prognostik keberhasilan operasi Kasai pada pasien yang berusia lebih dari enampuluh hari antara lain 1) hilangnya kuning pada enam bulan pascaoperasi, 2) kadar bilirubin total kurang dari $2 \mathrm{mg} / \mathrm{dL}$ pada usia tiga bulan, 3) kejadian kolangitis pascaoperasi kurang dari dua kali, 4) tipe atresia bilier, tipe 1 dan 2 , atau atresia bilier jenis yang didapat. Gambaran histologi hati sebagai faktor prognostik keberhasilan operasi Kasai masih memerlukan penelitian lebih lanjut. Perbedaan hasil penelitian Azarow KS dkk ${ }^{17}$ dan Davenport $\mathrm{M} \mathrm{dkk}^{13}$ mungkin disebabkan oleh perbedaan dalam menginterpretasikan gambaran histologi hati. Penelitian Davenport dkk. ${ }^{13}$ tidak menganalisis gambaran inflamasi lobular, nekrosis fokal, nekrosis jembatan, maupun gambaran empedu di zona-1 yang menurut Azarow dkk. ${ }^{17}$ memberikan prognosis lebih buruk. Penelitian di Inggris dan Perancis memperlihatkan hasil yang menarik, yaitu peran jumlah kasus yang ditangani suatu pusat penelitian terhadap keberhasilan operasi. Pusat penelitian yang menangani lebih dari lima sampai duapuluh kasus per tahun memperlihatkan keberhasilan operasi dan kesintasan yang lebih tinggi. ${ }^{8,16}$

Pada laporan kasus yang kami ajukan, pasien telah mengalami sepsis pada usia satu minggu dan infeksi saluran kemih berulang pada usia dua bulan. Sepsis dan infeksi saluran kemih dapat menimbulkan kolestasis intrahepatik, yang memberikan gejala kuning, buang air besar dempul, dan buang air kecil yang kuning pekat. Namun setelah infeksi teratasi, kadar bilirubin tidak pernah normal, dan buang air besar masih berwarna dempul. Dokter spesialis anak yang menangani sudah melakukan tindakan yang tepat dengan rencana melakukan pemeriksaan ultrasonografi hati dan merujuk pasien pada usia dua bulan, namun sayangnya keluarga pasien menolak karena masalah biaya. Pengenalan dini seorang dokter terhadap kolestasis ekstrahepatik sangat penting, sehingga pasien dapat dirujuk dan menjalani operasi Kasai pada usia sebelum enampuluh hari. Penelitian 
Mieli-Vergani G dkk. ${ }^{7}$ memperlihatkan alasan utama keterlambatan diagnosis adalah kegagalan petugas kesehatan dalam membedakan ikterus patologis dari ikterus fisiologis, yang diikuti oleh alasan lain yaitu pengabaian ikterus sampai terjadinya gagal tumbuh, kegagalan dalam pelayanan di rumah sakit, dan penolakan orangtua untuk dirujuk ke pusat pelayanan yang lebih berpengalaman, seperti halnya yang terjadi pada kasus kami.

Pasien datang ke RSCM pada usia lima bulan dan saat datang didapatkan tanda-tanda sirosis hepatis tidak terkompensasi, antara lain berupa asites, gambaran venektasi pada dinding perut, dan pemanjangan masa protrombin. Diagnosis sirosis bilier dibuktikan dengan pemeriksaan biopsi hati. Diagnosis pasti atresia bilier ditegakkan dengan pemeriksaan kolangiografi intraoperatif. Pada saat operasi, kondisi hati terlihat mengalami sirosis berat. Keluarga pasien telah mendapat penjelasan tentang keadaan pasien dan kemungkinan prognosis bila dilakukan operasi Kasai, namun keluarga menolak untuk menjalani operasi Kasai. Pasien menderita atresia bilier tipe 3 yang memperberat prognosis. Bila gambaran histologi hati preoperatif yang mempengaruhi prognosis diterapkan berdasarkan penelitian Azarow KS dkk. ${ }^{17}$, gambaran histologi hati pasien sebenarnya belum terlalu berat. Jarak antara dilakukannya biopsi hati preoperatif dan operasi berkisar satu minggu, dan hal ini memungkinkan untuk terjadinya kerusakan hati yang lebih lanjut. ${ }^{17}$ Namun gambaran biopsi hati intraoperatif memperlihatkan kerusakan hati yang lebih kurang sama dibandingkan sebelumnya. Dengan demikian, operasi Kasai pada pasien ini masih mungkin dapat memberikan manfaat, apabila kemudian kadar bilirubin kembali ke kadar normal dalam enam bulan pascaoperasi dan kejadian kolangitis asenden pascaoperasi terjadi kurang dari dua kali. Luaran tersebut sangat dipengaruhi oleh pengalaman pusat pelayanan yang bersangkutan dalam melakukan operasi dan perawatan pascaoperasi.

\section{Kesimpulan}

Operasi Kasai tetap merupakan pilihan tata laksana utama pasien atresia bilier. Peran operasi Kasai dalam tata laksana pasien atresia bilier semakin nyata dengan keterbatasan melakukan transplantasi hati di Indonesia. Meskipun kesintasan pascaoperasi Kasai menurun dengan bertambahnya usia, sejumlah pasien yang dioperasi pada usia lebih dari enampuluh hari masih memiliki kesintasan hingga 10-15 tahun pascaoperasi. Keberhasilan operasi Kasai dipengaruhi oleh berbagai faktor, antara lain faktor preoperatif berupa gambaran histologi hati dan tipe atresia bilier, faktor pascaoperatif berupa kadar bilirubin serum dan kejadian kolangitis asenden pascaoperasi, serta pengalaman sentra yang bersangkutan dalam melakukan operasi Kasai dan perawatan pascaoperasi. Kemampuan petugas kesehatan primer maupun dokter spesialis anak dalam mendeteksi dini atresia bilier dan melakukan rujukan, merupakan hal krusial yang berdampak pada kesintasan jangka panjang pasien dengan atresia bilier.

\section{Daftar Pustaka}

1. Peterson C. Pathogenesis and treatment opportunities for biliary atresia. Clin Liver Dis 2006;10: 73-88.

2. Shneider BL, Brown MB, Haber B, Whitington PF, Schwartz K, Squires R, dkk. A multicenter study of the outcome of biliary atresia in the United States, 1997 to 2000. J Pediatr 2006;148:467-74.

3. Schreiber R, Barker CC, Roberts EA, Martin SR, Alvarez F, Smith L, dkk. Biliary atresia: the Canadian experience. J Pediatr 2007;151:659-65.

4. Hung P, Chen C, Chen W, Lai H, Hsu W, Lee P, dkk. Long-term prognosis of patients with biliary atresia: A 25 year summary. J Pediatr Gastroenterol Nutr. 2006;42:190-5.

5. Emblem R, Stake G, Monclair T. Progress in the treatment of biliary atresia: A plea for surgical intervention within the first two months of life in infants with persistent cholestasis. Acta Pediatr 1993;82:971-4.

6. Karrer FM. Biliary atresia registry, 1976-1989. J Pediatr Surg. 1990;25:1076-80.

7. Mieli-Vergani G, Portman B, Howard ER, Mowat AP. Late referal for biliary atresia - missed opportunities for effective surgery. Lancet 1989;i:421-3.

8. Chardot C, Carton M, Spire-Bendelac N, Pommelet CL, Golmard J, Auvert B. Prognosis of biliary atresia in the era of liver transplantation: French national study from 1986-1996. Hepatology 1999;30:606-11.

9. Serinet M, Wildhaber BE, Broué P, Lachaux A, Sarles J, Jacquemin E, dkk. Impact of age at Kasai operation on its results in late childhood and adolescence: A rational basis for biliary atresia screening. Pediatrics 2009;123:1280-6. 
10. Oxford Centre of Evidence-based Medicine. Oxford centre for evidence-based medicine levels of evidence (March 2009). Diunduh dari: http://www.cebm.net/index. aspx?o=1025. Diakses tanggal 1 November 2009.

11. Chardot C, Serinet M. Prognosis of biliary atresia. What can be further improved? J Pediatr 2006;148:432-4.

12. Serinet M, Broué P, Jacquemin E, Lachaux A, Sarles J, Gottrand F, dkk. Management of patients with biliary atresia in France: Results of a decentralized policy 19862002. Hepatology 2006;44:75-84.

13. Davenport M, Puricelli V, Farrant P, Hadzic N, MieliVergani G, Portmann B, dkk. The outcome of the older ( $\geq 100$ days) infant with biliary atresia. J Pediatr Surg 2004;39:575-81.

14. Toyosaka A, Okamoto E, Kawamura E, Okasora T,
Nosa K, Tomimoto Y, dkk. Successful Kasai operation for biliary atresia in a 9 month old. J Pediatr Surg 1993;28:1557-60.

15. Wildhaber BE, Coran AG, Drongowski RA, Hirschl RB, Geiger JD, Lelli JL, dkk. The Kasai portoenterostomy for biliary atresia: A review of a 27-year experience with 81 patients. J Pediatr Surg 2003;38:1480-5.

16. McKiernan, Baker AJ, Kelly DA. The frequency and outcome of biliary atresia in the UK and Ireland. Lancet. 2000;355:25-9.

17. Azarow KS, Phillips J, Sandler AD, Hagerstrand I, Superina R. Biliary atresia: Should all patients undergo a portoentersotomy? J Pediatr Surg 1997;32:168-74.

18. Ishitani MB. Biliary atresia and the Kasai portoenterostomy: never say never? Liver Transplant 2001;7:831-2. 